\title{
Food Price Volatility: Causes \& Challenges
}

\author{
M.J.Patel* \\ * Tata Chemicals Employees Union, Gujarat, India.
}

\begin{abstract}
After independence of INDIA, PAKISTAN \& BANGLADESH, minimum wage in 1947, was at par and corresponding exchange rate was also at par with that of US Dollar. Countries, simultaneously, created with all kinds of similarities, after 65 years, exhibit large variations in monetary considerations and exchange rate in India at Rs.62.40/US\$, in Bangladesh exchange rate at BDT 78/US\$ and in Pakistan exchange rate at Rs.108/US\$. Neighbours use trade policy and raise minimum wage to insulate their domestic food price. Natural conclusion is that rise in ratio of minimum wage drags exchange rate with respect to that of trading partners. This behaviour raises volatility of food price across neighbours. Because insulation policy exports volatility elsewhere. Comparison between peer States becomes easier and may not require any empirical test proof for natural conclusions. This paper emphasises synchronising, across neighbours \& globally, up-rating minimum wage to contain food price volatility.
\end{abstract}

Index Terms: Food Price Volatility, Minimum Wage, Exchange Rate, Minimum Wage drags Exchange Rate

\section{Introduction}

In 1947 INDIA was bifurcated, simultaneously, into three independent countries, INDIA, PAKISTAN and BANGLADESH and having currency rate at par with that of US Dollar. Despite having similarity in socieoeconomic pattern, after 65 years, we can observe large variations in value of their currencies as well in food prices. Explore reasons behind these variations.

\section{Objective of the Study}

2.1 To highlight the relationship of food price \& inflation.

2.2 To highlight the relationship of food price \& minimum wage.

2.3 To highlight the relationship of food price \& minimum wage \& exchange rate \& international trade.

2.4 To explore new monetary tools to contain inflation $\&$ food price volatility.

\section{Research Methodology}

Comparison of progressive minimum wage and corresponding value of currencies of three countries \& other neighbour \& other leading economies is with that of US Dollar. Minimum wages data are obtained from Labour Dept publications. Whereas exchange rate data are obtained from Central Bank publications.WPI \& food prices data are obtained from DEA, India. Hourly wages have been converted to daily/monthly wages. It is assumed that the exchange rate is reflection of entire population of the country. But difficulty lies in measurement of progressive gross wages of entire work force. Minimum wage earners are most defined group. Rise in wage of one larger group causes ripple effect on other groups and therefore price rises in the over-all economy. Not only that the ratio of neutralisation against inflation to bottom line employees is much higher than other employees. Therefore sample-size of 'minimum wage earners' is well justified.

\subsection{History}

\section{Study of the research}

A heavy monsoon season destroyed agricultural crops and led to a plague epidemic claiming nearly 10 percent of the population of Ahmadabad in 1917.During the period of intense plague outbreak from August 1917 to January 1918 the workers of the textile mills, in Ahmadabad, Gujarat, India, were paid 'plague bonus', up to $80 \%$ of gross wages, in an attempt to discourage the workers from fleeing during an outbreak of a plague. However, when the employers announced their intention to discontinue the 'plague bonus' as the plague epidemic subsided in January 1918, worker demanded dearness allowance @ of 50\% of their wages on the July salaries in order to sustain their livelihood against wartime inflation. Inflation, at that time doubled the prices of food-grains. Since then concept of dearness allowance is evolved. With a view to neutralise food price-rise DA system is being continued in India and Pakistan. This DA system is fuelling higher and higher inflation spiralling effect on food price-rise. With a view to protect workers, in un-organised sector, against inflationary forces minimum wage are implemented. 
Abstract of Report on 'Did the National Minimum Wage Affect UK Prices? Sept-2009,' [1]. It is hard to find much evidence of significant price changes in the months that correspond to the updating of NMW.However over the longer term, prices in several minimum wage sectors-notably take-away foods, canteen meals, hotel services and domestic services-do appear to have risen significantly faster than prices of nonminimum wage sectors. These effects were particularly significant in the four years immediately after the introduction of the minimum wage.'

The UK minimum wage had been introduced in April 1999, after reforms in the 1980s had ended collective bargaining in many industries and abolished the former system of wage councils. More than 200 countries, as part of International Labour Organisation convention so also national socieo-economic policy, are implementing minimum wage.

\subsection{Charts}

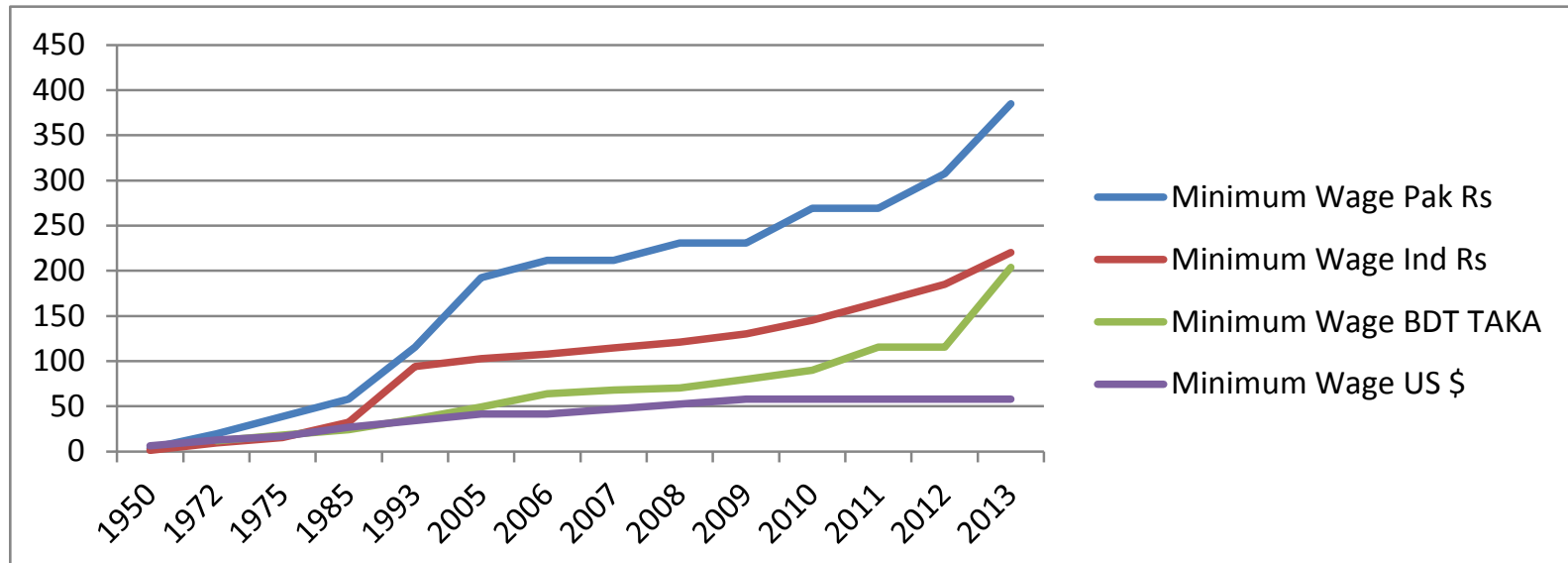

Figure-1 Minimum Wage Comparison Pakistan, India, Bangladesh \& US

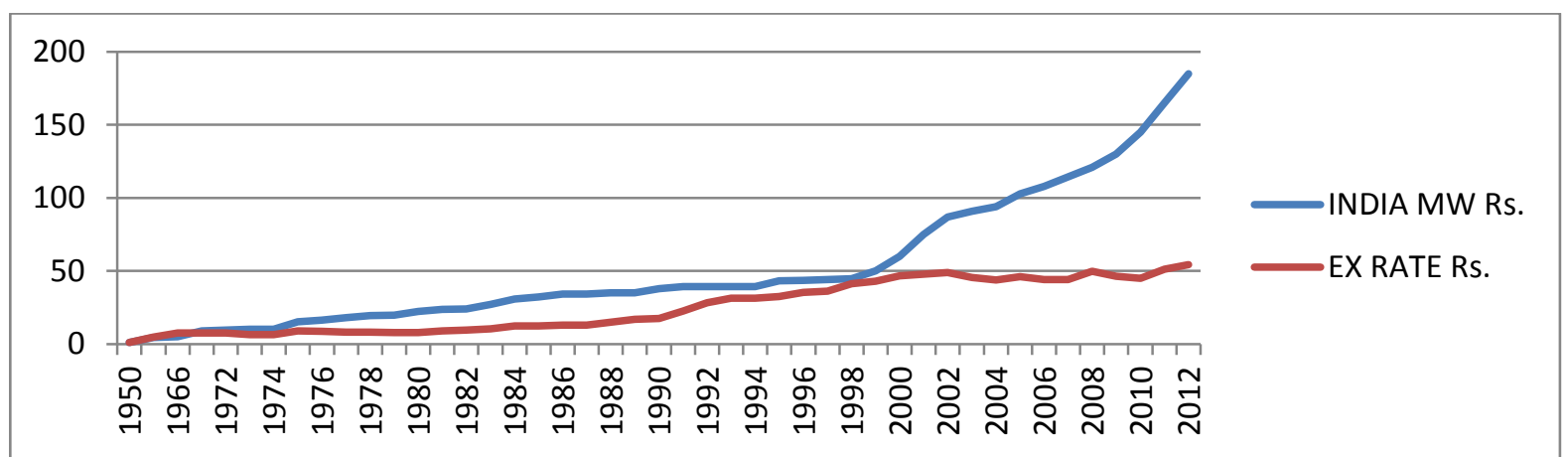

Figure-2 India Minimum Wage v/s Exchange Rate Indian Rs. /\$

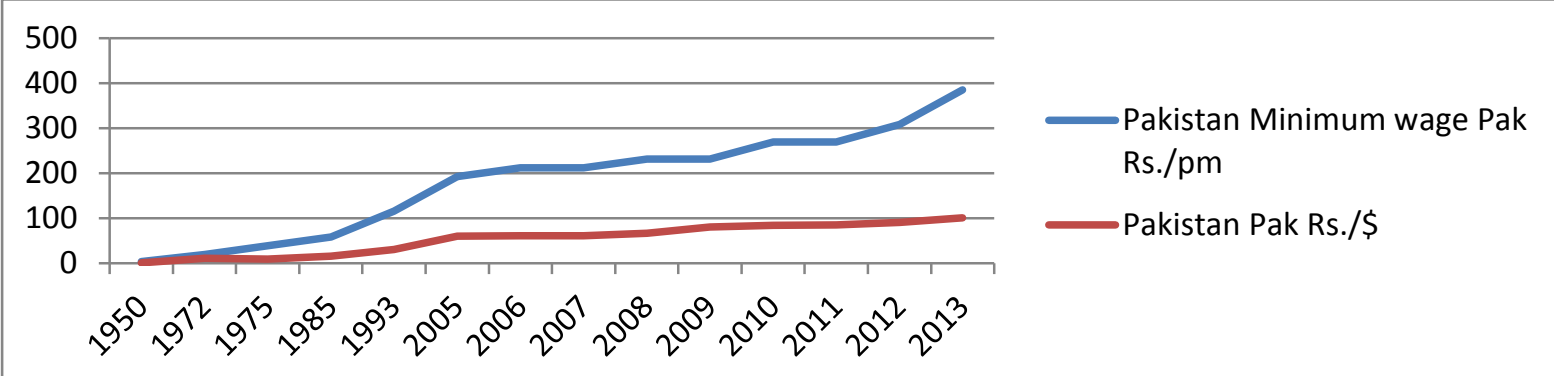

Figure-3 Pakistan Minimum Wage v/s Exchange Rate Pakistan Rs. / 
Food Price Volatility: Causes \& Challenges

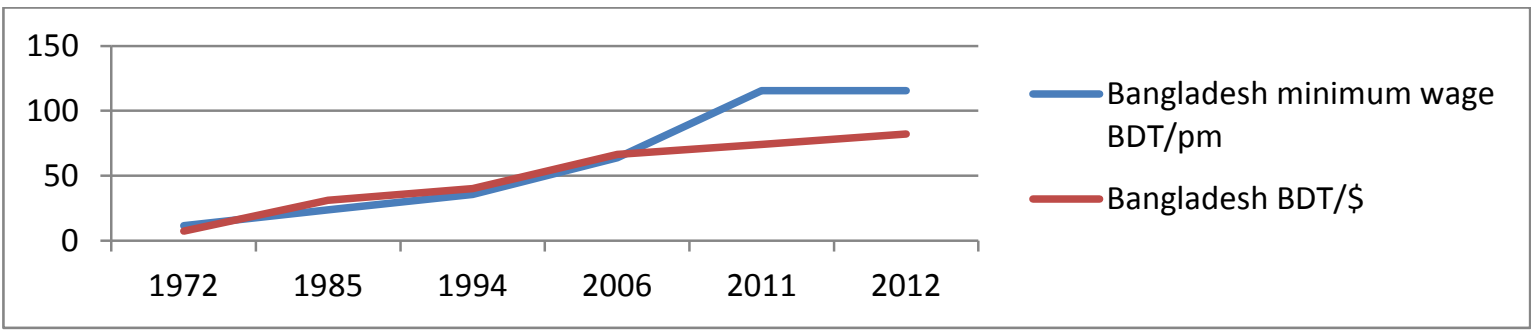

Figure-4 Bangladesh Minimum Wage v/s Exchange Rate Bangladesh BDT/\$

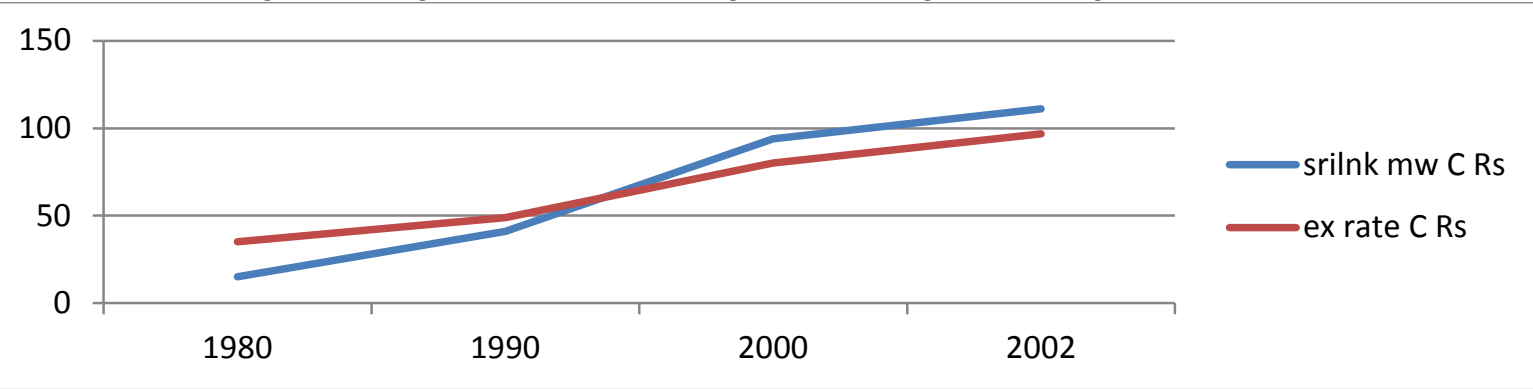

.Figure-5 Sri Lanka minimum wage v/s Exchange Rate Sri Lanka Rs. C/\$

Data Source Department of Census and Statistics Sri Lanka, [2].

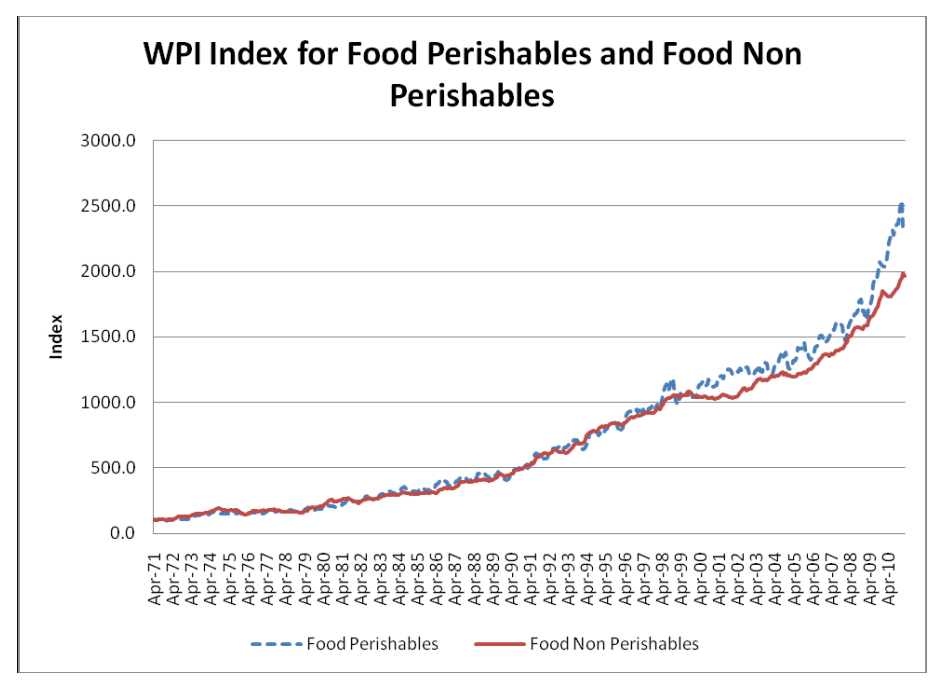

Figure-6 with Fig.18 reveals that volatility in India food prices corresponds to minimum wage revision in every Apr \& Oct, Data from Understanding India inflation and controlling it, BASU \& MARK, [3].

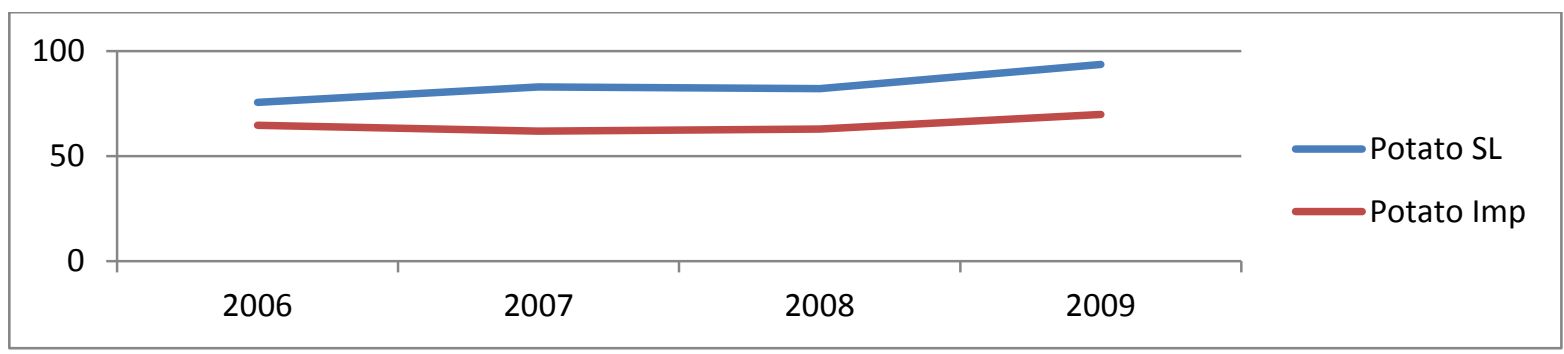

Figure-7 Sri Lanka Potato Price

Data Source Department of Census and Statistics Sri Lanka 


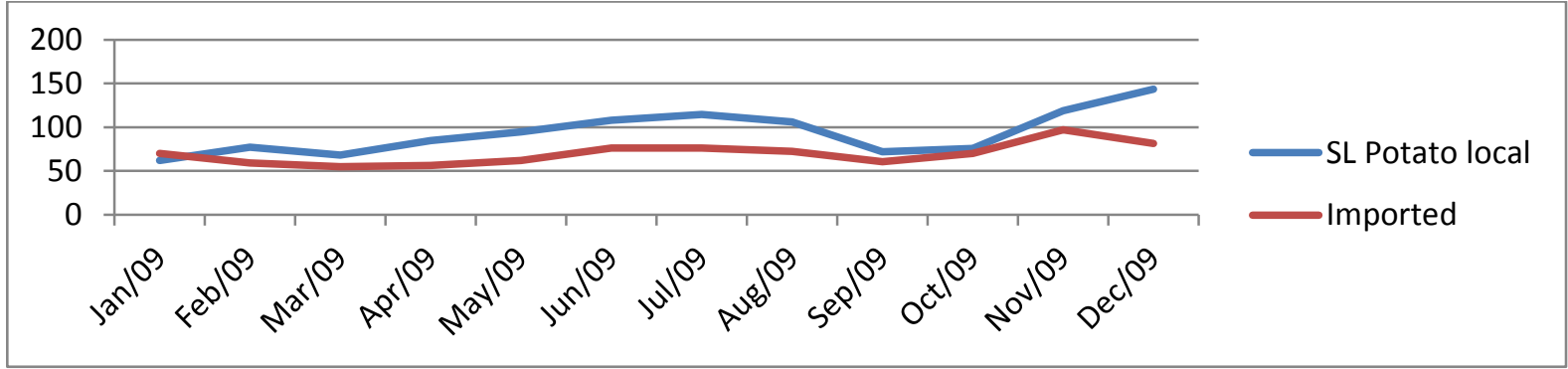

Figure-8 Sri Lanka Potato Price Data Source Department of Census and Statistics Sri Lanka

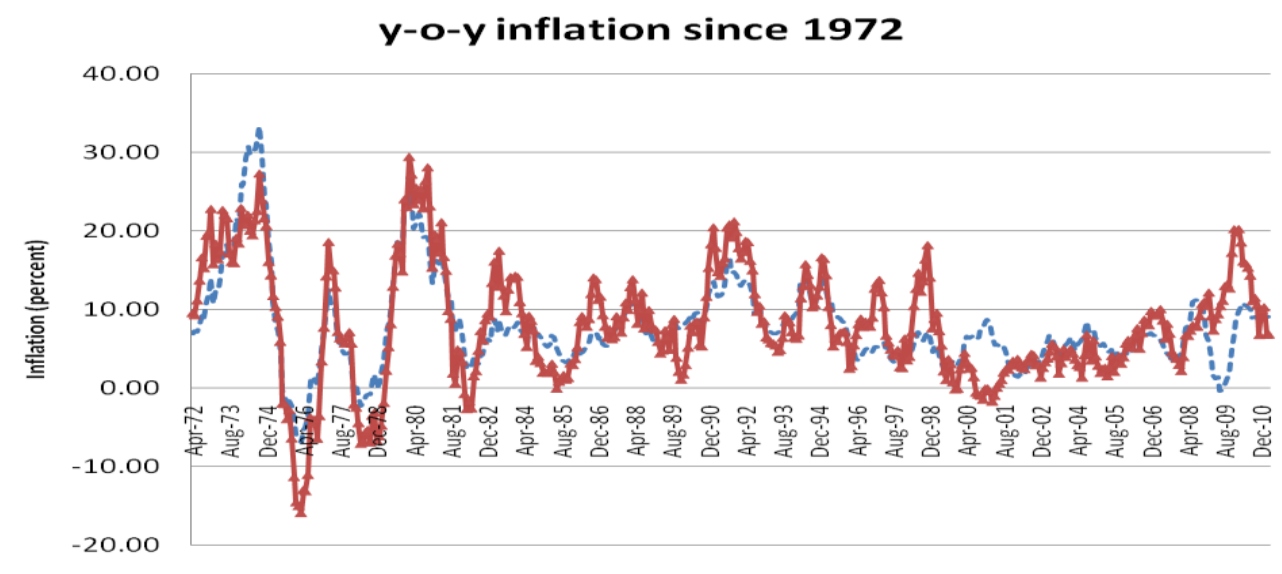

----All Commodities

$\longrightarrow$ Food

Figure -9 with Fig. 18 reveals that volatility in India food prices corresponds to minimum wage revision in every Apr \& Oct, and bias towards food-items. Data from Understanding India inflation and controlling it, Basu \& Mark.

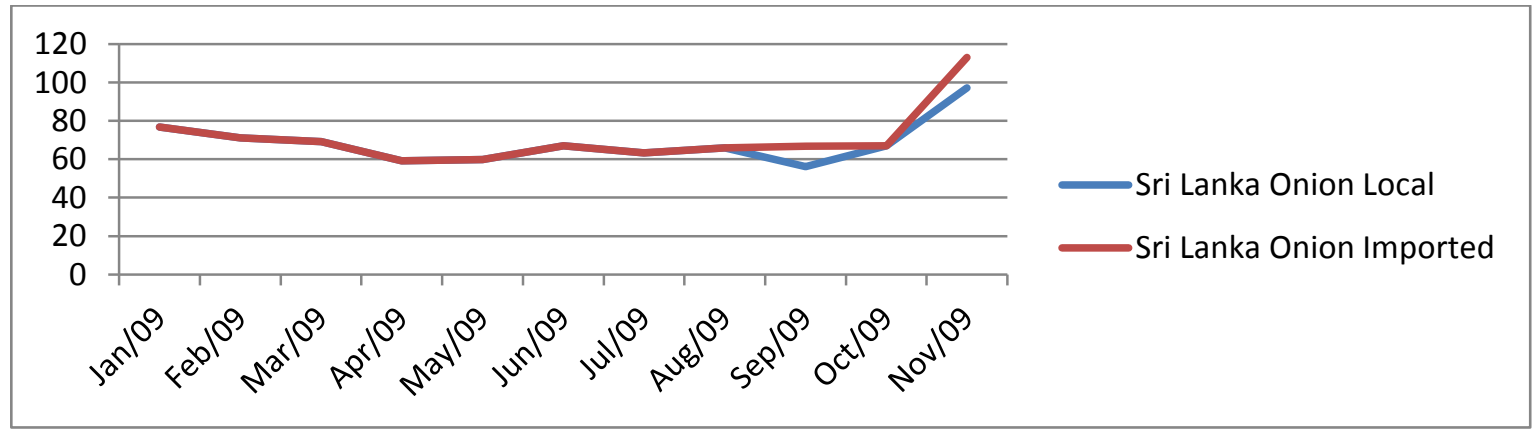

Figure-10 Sri Lanka Onion Price Data Source Department of Census and Statistics Sri Lanka

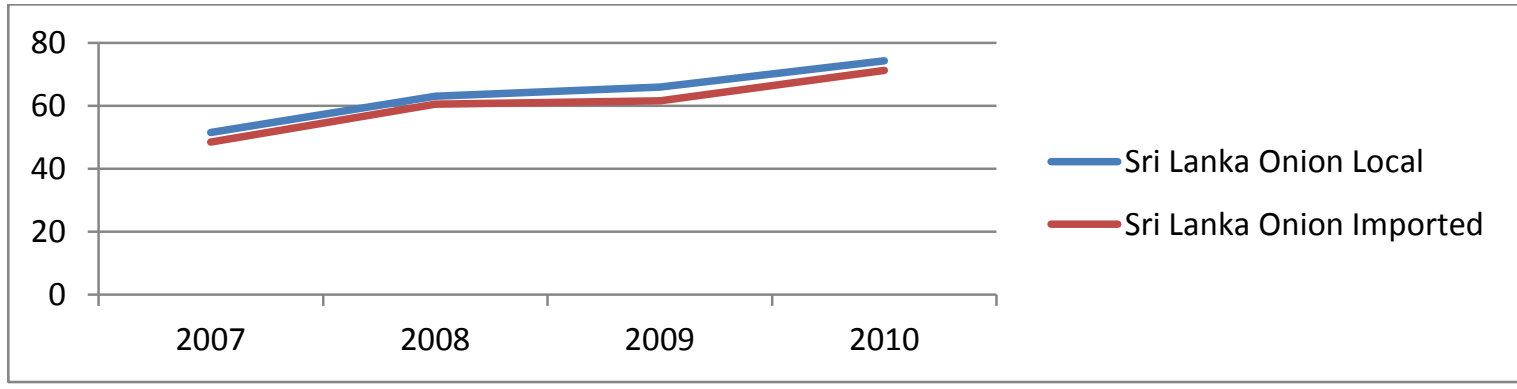

Figure-11 Sri Lanka Onion Price Data Source Department of Census and Statistics Sri Lanka 


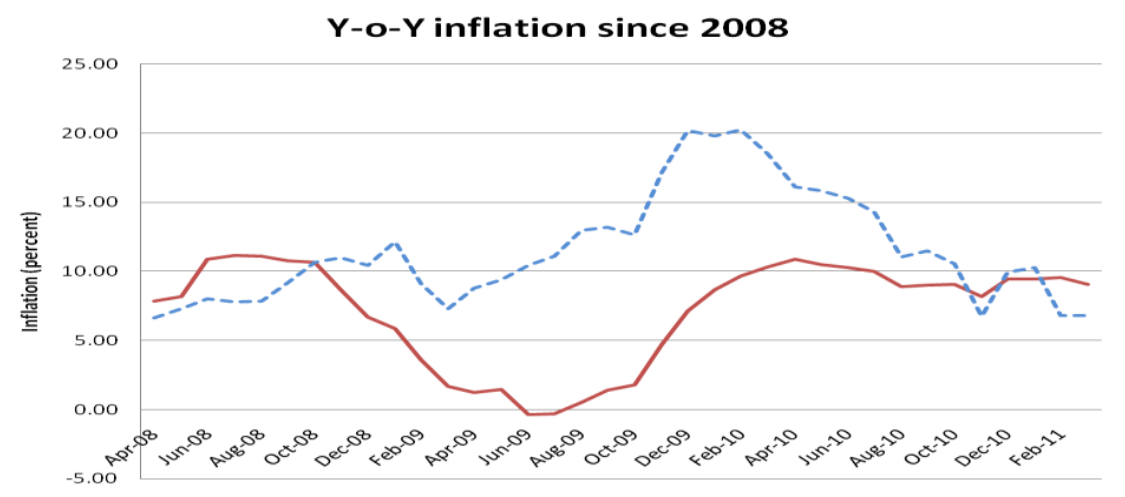

Figure-12 Distinct divergence between prices of Food and All Commodities and bias towards food-inflation. Data from Understanding India inflation and controlling it, BASU \& MARKS.

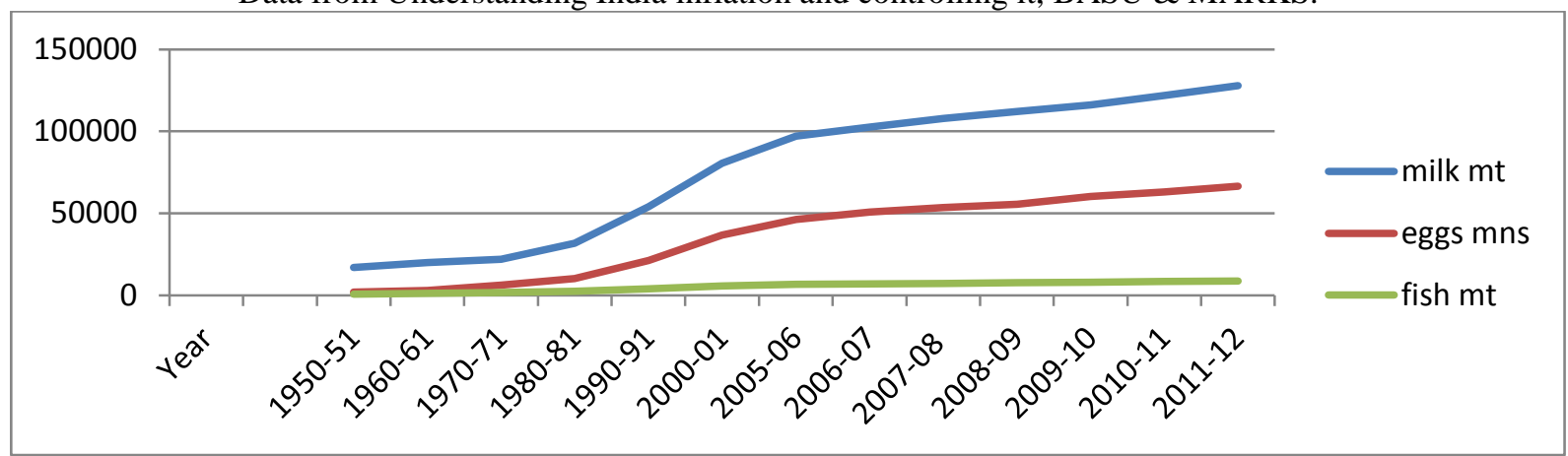

.Figure- 13 Milk, Egg \& Fish production, $\mathrm{m}=$ million, in India.

Data Source: RBI

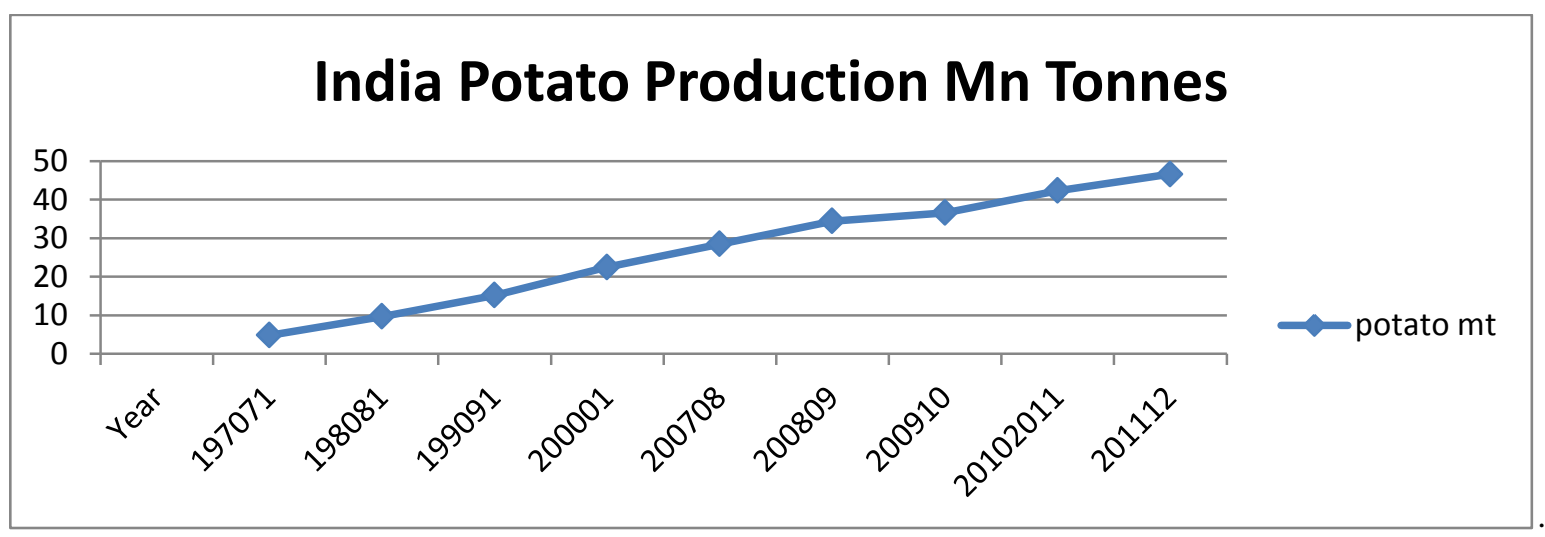

Figure-14 Data Source: RBI

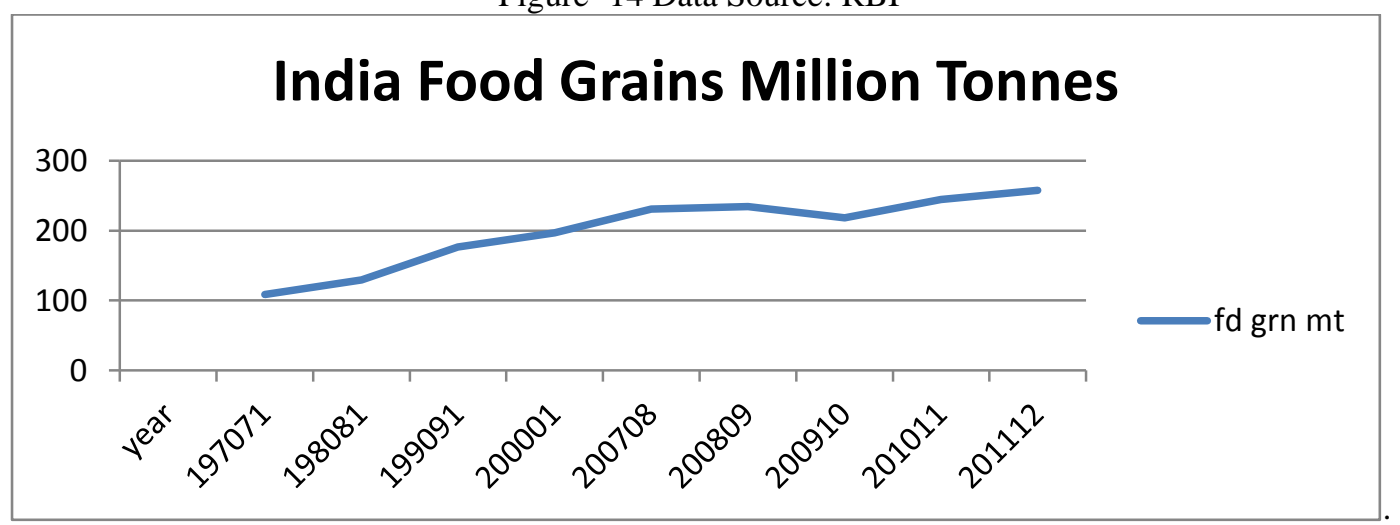

Figure- 15 Data Source: RBI 


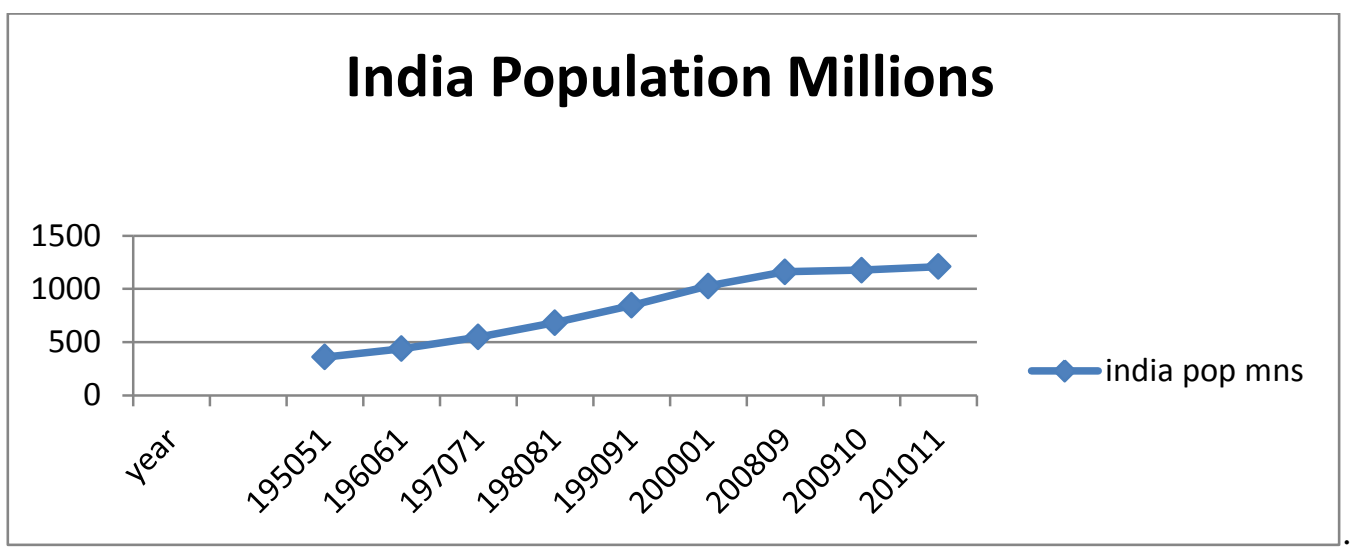

Figure- 16 Data Source: RBI

\subsection{Observations}

Above Fig.1 \& Fig.6, 9, 12 show that food price-rise corresponds to India minimum wage-rise. And above Fig. 2, 3, 4 \& 5 further shows that if minimum wage revised upwardly than currency value falls with respect to that of other country and therefore exchange rate makes re-alignment and settles at revised correct value. Intermediate appreciation in Indian Rupee, Fig.2, can be well explained, in Fig.17, wherein impact of simultaneous up-rating of minimum wages of trading partners, US \& India, evidently reflects. Similar evidence also can be seen in the case of UK v/s US, in Fig.18.

\subsection{Classic case of onion trading in the Region}

Bangladesh, Sri Lanka \& Pakistan, as per APEDA Agri Exchange[4], imports onions from India,557618 Metric Tons @ realising price Rs 8050 Million i.e. less than Rs $15 / \mathrm{Kg}$; \& corresponding retail price in India was Rs.35/Kg. Above Fig.10 \& Fig.11 suggest that price of imported onions in Sri Lanka are less than local onions. On the other hand 'India has abolished import taxes on onions in the latest attempt to control prices of the staple food which have more than doubled in a week. The price of onions has risen to an eye-watering 85 rupees, $\$ 1.87$; 1.20 , per kg from 35 rupees only last week.'22nd Dec 2010, BBC. Fig.7 \& Fig. 8 suggest that price of imported potatoes in Sri Lanka are less than local potatoes. These are glaring examples of causes of food price volatility.

\subsection{Minimum Wage}

Abstract of Report on 'Did the National Minimum Wage Affect UK Prices?' Sept-2009, evidently suggests that price rise in food product is consequent upon rise in minimum wage. This establishes that there is direct relationship with the ratio of minimum wage-rise with the food price-rise. As such rise in wages of one of the larger group of workers also causes ripple effect on other groups and therefore price rises in the over-all economy and more particularly in essential goods like food. Prices of domestic goods remain less as long as wages are less. The UK minimum wage had been introduced in April 1999, after reforms in the 1980s had ended collective bargaining in many industries and abolished the former system of wage councils. More than 200 countries, as part of International Labour Organisation convention so also national socieo-economic policy, are implementing minimum wage. Adjustments in minimum wages are made in number of countries twice or more in a year, and in many countries once in two or three years, in large number of countries at irregular intervals of several years. In Costa Rica and Mexico the acceleration of inflation has caused an official shift in policy resulting in annual instead of biennial revisions. In the case of compelling adjustments the decline in the real value of minimum wage is sometimes dramatic and the size of the increase required to return them to realistic levels so great that they cannot avoid being disruptive. And such disruptive adjustments ultimately play havoc on international exchange and trades. System of fixing and up-rating of minimum wage differs across countries. In India this is being done on the basis of guide lines of Indian Labour Conference. Indian Labour Conference, 1957, suggested norms that at a given point of time value of goods \& services (a) three consumption units per earner (b) minimum food requirement of $2700 \mathrm{cal} /$ day/per adult (c) cloth requirement of 72 yards per annum per earner (d) rent corresponding to area provided under Industrial Housing Scheme (e) fuel, lighting etc at $20 \%$ of total minimum wages (f) children education, medical, recreation, old age provision etc at $25 \%$ of total minimum wages, shall be amount of total minimum wage,[5]. In Sri Lanka the prescribed nutritional level varies widely from 1710 to $2530 \mathrm{cal} /$ day, [6]. Unfortunately uniformity is missing in norms of fixing and adjustment of minimum wage. An Indian norm appears to be trend setter. Composition of food bundle making 
2700 calorie is the core part of minimum wage. Said food bundle is on top of the list of traded goods and therefore makes, minimum wage, rate sensitive.

So also one cannot deny that incentivised wage expects higher productivity \& higher efficiency. Whereas in the case of minimum wage productivity is pegged at fixed level. Therefore prices of domestic goods also changes in alignment with revised wage. Present practice of providing neutralisation against inflation, while revising minimum wage, appears to be counter-productive.

\subsection{Exchange Rate}

Minimum wages at US in the year 1938 were $\$ 43 / \mathrm{pm}$ \& in the year 1950 were $\$ 130 / \mathrm{pm}$, whereas minimum wages at India in the year 1950 were Rs72/pm \& in Pakistan were Rs. 90/pm and exchange rate, at India \&Pakistan, was almost at par with Dollar. And in the year 1972 minimum wages in India were Rs.252/pm and in Pakistan were Rs.500/pm and in Bangladesh were BDT 300/pm. Corresponding exchange rate, In 1972 for 1 Dollar, in India was Rs.7.28 and in Pak exchange rate was Rs.11 and in Bangladesh exchange rate was BDT 7.28. Whereas, at present, in the year 2013 minimum wage at US is \$ 1257/pm \& minimum wages in the year 2013 at India is Rs.4810/pm and at Pakistan is Rs.10000/pm and in Bangladesh is BDT 5300/pm. And corresponding exchange rate is Rs.62.40 for India and Rs.100.25 for Pakistan and in Bangladesh is BDT 77.75 for one Dollar. Adjustments in minimum wage are made twice in a year, April \& Oct, in India. In Bangladesh minimum wage revision was kept on hold for more than three years. Whereas in the case of Pakistan revision of minimum wage is irregular \& irrational, therefore causing disruptive movement in exchange rates. Evidently proves that minimum wage is being treated as welfare measure rather than monetary tool.

Rise in ratio of minimum wages of trading partners causes disruptive movement in their exchange rate \& further creates trade barriers in essential goods. Evils of un-consulted up-rating, across neighbours, immediately percolate on perishable food items. Unilateral revision of minimum wage by either of the trading partners shall compel other party to review \& revise exchange rate and prices of goods. Price-rise in domestic food, consequent upon wage-rise, compels devaluation of currency with respect to that of trading partners. Whereas simultaneous up-rating allows keeping the ratio of minimum wage more or less same, which may help to maintain stability in exchange rate was the fundamental objective of the Bretton Wood Regime.

\subsubsection{Minimum wage: as an Exchange Rate determinant factor}

Exchange rate, proportionately, varies with rise and fall in ratio of wages of employed persons of the concerned economy with respect to that of other economy as follow.

$$
:\left(\begin{array}{c}
\text { Revised } \\
\text { Exchange } \\
\text { Rate }
\end{array}\right)=\left(\begin{array}{c}
\text { Existing } \\
\text { Exchange } \\
\text { Rate }
\end{array}\right) *\left(\begin{array}{c}
\left(\begin{array}{c}
\text { Existing } \\
\text { Ratio of } \\
\text { Wages }
\end{array}\right. \\
\left\{\begin{array}{c}
\text { Revised } \\
\text { Ratio of } \\
\text { Wages }
\end{array}\right.
\end{array}\right)
$$

Keeping in view the difficulty in measurement of progressive gross revised wage consider opting minimum wage as follow. Number of employees in minimum wage at the time of up-rating \& quantum of rise in wage is easily accessible.

Possible impact of minimum wage, at the time of up-rating, on exchange rate can be ascertained as follow.

$$
\left.:\left(\begin{array}{c}
\text { Revised } \\
\text { Exchange } \\
\text { Rate }
\end{array}\right)=\left(\left(1-\frac{\{p\}}{\{100\}}\right) *\left(\begin{array}{c}
\text { Existing } \\
\text { Exchange } \\
\text { Rate }
\end{array}\right)\right)+\left(\left\{\frac{\{p\}}{\{100\}}\right\} *\left\{\begin{array}{c}
\text { Existing } \\
\text { Exchange } \\
\text { Rate }
\end{array}\right\} * \frac{\left.\begin{array}{c}
\text { Existing } \\
\text { Ratio of Minimum } \\
\text { Wages }
\end{array}\right\}}{\left\{\begin{array}{c}
\text { Revised } \\
\text { Ratio of Minimum } \\
\text { Wages }
\end{array}\right.}\right\}\right)
$$

Ratio of Wages $=($ Revised/Existing $)$ Ratio of wages of trading partners.

$p=$ percentage of population beneficiary on revision of minimum wage to total population

\subsubsection{Illustration}

As per (2)

$\left(\begin{array}{c}\text { Revised } \\ \text { Exchange } \\ \text { Rate }\end{array}\right)=\left(\left(1-\frac{\{p\}}{\{100\}}\right) *\left(\begin{array}{c}\text { Existing } \\ \text { Exchange } \\ \text { Rate }\end{array}\right)\right)+\left(\left\{\frac{\{p\}}{\{100\}}\right\} *\left\{\begin{array}{c}\text { Existing } \\ \text { Exchange } \\ \text { Rate }\end{array}\right\} * \frac{\left.\begin{array}{c}\text { Existing } \\ \text { Ratio of Minimum } \\ \text { Wages }\end{array}\right\}}{\left\{\begin{array}{c}\text { Ravised } \\ \text { Rat Minimum } \\ \text { Wages }\end{array}\right\}}\right)$

Case -1

7.5\% Bangladeshi possible beneficiary consequent upon revision of minimum wages of 3.5 million RMG Workers from BDT 3000/pm to BDT 5300/pm effective Dec 2013 may have impact on Exchange Rate from BDT 77.75/1US\$ to BDT 82.22/1US\$i.e,4.47\%@77.75.

(i) Mini. Wage BDT3000/pm \& Rev.Min Wage BDT 5300/pm

(iii) Mini. Wage US \$1257/pm \&

(ii) $\mathrm{P}=$ percentage covered $=7.5$

(iv) Exch. Rate BDT77.75/1US \$ 
Case-2

Rev. Exch. Rate, as per (2), 1 US \$= BDT 82.22 from BDT 77.75

4.7\% Americans possible beneficiaries consequent upon possible revision of minimum wage from 7.25 US $\$ / \mathrm{hr}$ to 10 US \$/hr effective from Jan 2014 may have impact on Exchange Rate from BDT 82.22/1US\$ to BDT 78.8/1US\$ i.e., $1.76 \% @ 82.22$.

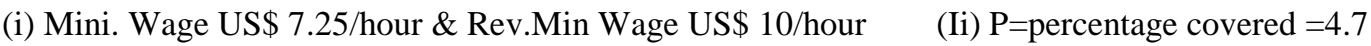
(iii) Mini. Wage BDT 5300/pm
(iv) Exchange Rate BDT82.22/1US \$ i.e. 1 BDT=.01238 US \$

Rev. Exch. Rate, as per (2), 1 US \$=BDT 80.77 from BDT 82.22

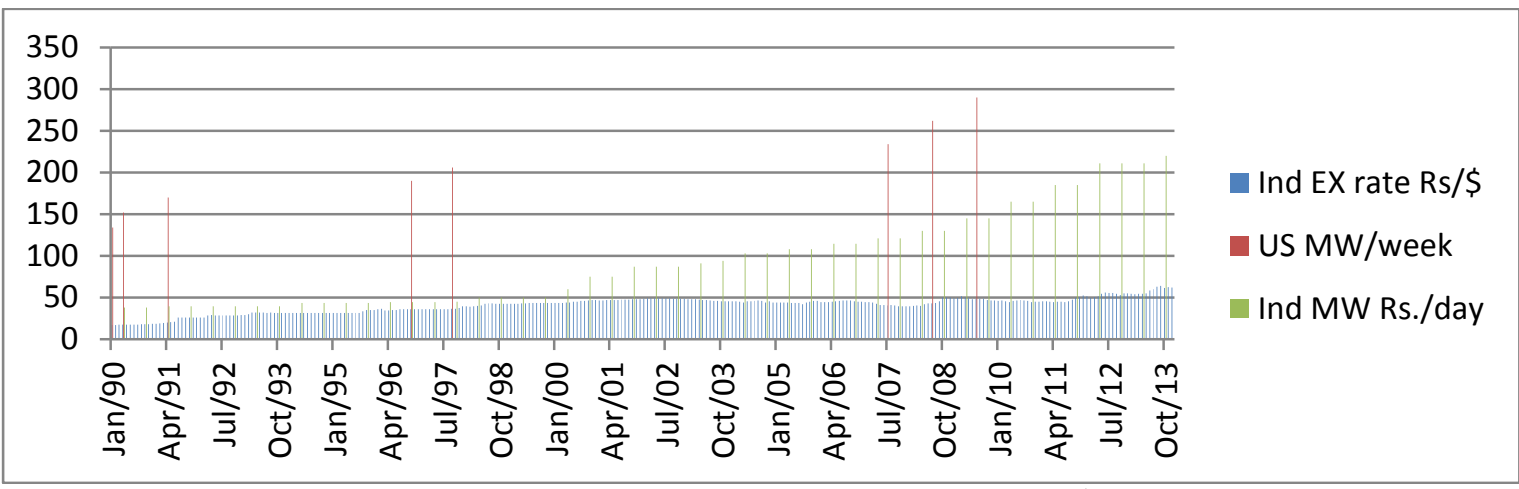

Figure-17, cumulative effect of minimum wage on Indian currency Rate Rs $/ \$$

Above Fig. 17 shows that as and when Indian minimum wage rises, April \& Oct, Indian Rupee depreciates. Comparison with monthly column chart \& daily wage rate evidently reflects the relationship with exchange rate. So also as and when US minimum wage rises Indian Rupee appreciates.

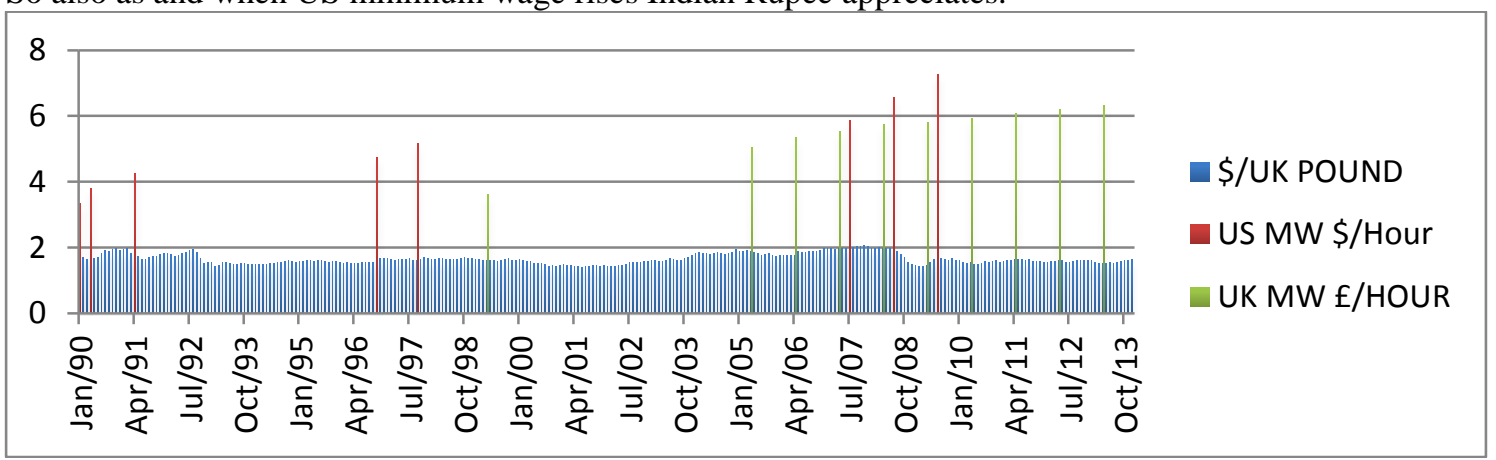

Figure-18, cumulative effect of minimum wages on currency Rate \$/UK Pound

Fig.18 shows that, post Bretton Wood Regime, as and when UK minimum wage rises US Dollar appreciates. So also as and when US minimum wage rises UK Pound appreciates. Comparison with monthly column chart \& hourly wage rate evidently reflects the relationship with exchange rate.

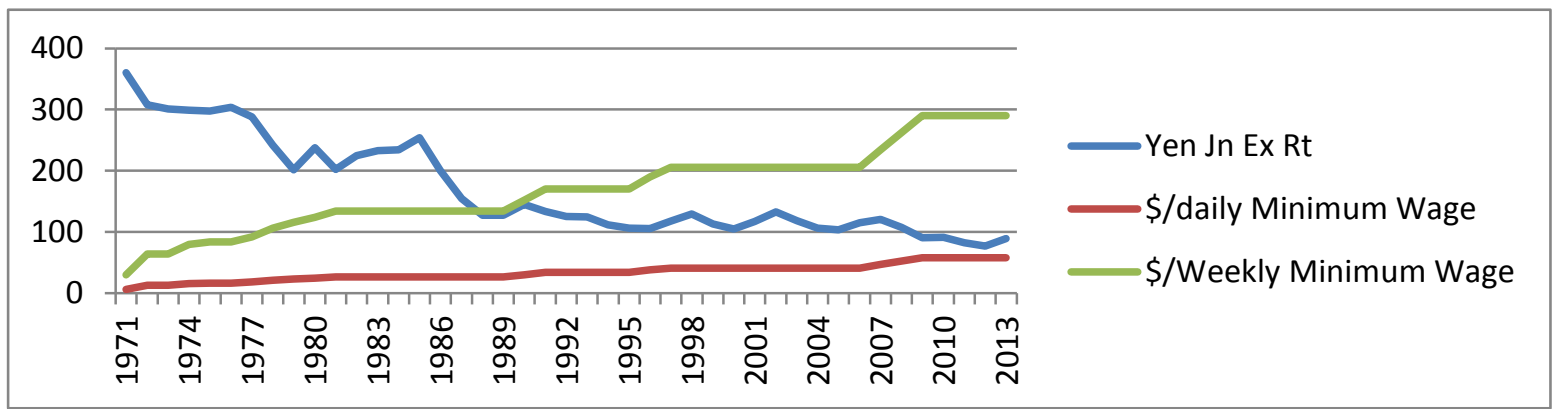

Figure-19 Exchange Rate Yen/\$ vs. US minimum wage \$/week

Above Fig. 19 shows that as \& when US minimum wage rises Japanese Yen appreciates. Comparison with weekly wage rate evidently reflects the relationship with the exchange rate.

Under identical circumstances comparison in value of money of particular goods, simultaneously, produced by set of workers across borders, relatively, varies with overnight up-rating minimum wage. Basket of bundle of food goods making $3 * 2700$ calories specified under minimum wage have greater relevance than basket of goods 
specified under doctrine of 'PPP', purchasing power parity. Therefore empirical verifiability of variation relationship between minimum wage \& exchange rate is not much of relevant for the purpose of this paper.

\subsubsection{Impact of Collapse of Bretton Wood Exchange Regime}

Some authors found that since the break down of the Bretton Woods exchange regime, real commodity prices have exhibited increasing variability since early 1970, Chu and Morrison (1984), Reinhart and Wickham (1994) and Cuddington and Liang (1999),[7]. At this juncture it is important to explore why the Bretton Woods exchange regime broken-down? The relevant period, above Fig.19, suggest that exchange rate volatility followed by multiple revision in US Federal Minimum Wage \& extending benefits to farm labours \& others under its purview, \{The 1966 Amendments extended coverage to State and local government employees of hospitals, nursing homes, and schools, and to laundries, dry cleaners, and large hotels, motels, restaurants, and farms. Subsequent amendments extended coverage to the remaining Federal, State and local government employees who were not protected in 1966, to certain workers in retail and service trades previously exempted, and to certain domestic workers in private household employment.\},[8], may be the fundamental reason in breakdown of the Bretton Woods Exchange Rate Regime.

$14 \%$ un-protected Americans were brought first time under FLSA vide 'the War Against Poverty Scheme' at equivalent Gold Conversion rate \$35/oz [Bretton Wood Regime] and average wage rise from 70 Cents to 160 Cents \& 8\% Existing Americans were benefited under up-rating minimum wage from 125 Cents to 160 Cents.

Total impact can be ascertained as follow

$$
\begin{aligned}
& :\left(\begin{array}{c}
\text { Revised } \\
\text { conversion } \\
\text { Rate }
\end{array}\right)=\left(\left(1-\frac{\{p 1\}}{\{100\}}-\frac{\{p 2\}}{\{100\}}\right) *\left(\begin{array}{c}
\text { Existing } \\
\text { conversion } \\
\text { Rate }
\end{array}\right)\right)+\left(\left\{\frac{\{p\} 1}{\{100\}}\right\} *\left\{\begin{array}{c}
\text { Existing } \\
\text { conversion } \\
\text { Rate }
\end{array}\right\} *(r 1)\right)+\left(\left\{\frac{\{p 2\}}{\{100\}}\right\} *\left\{\begin{array}{c}
\text { Existing } \\
\text { conversion } \\
\text { Rate }
\end{array}\right\} *(r 2)\right)(3) \\
& \text { p1 }=14 \%, \text { p2=8\%, Existing Con. Rate }=\$ 35 / \mathrm{oz} \text {, Rev. Wage Ratio r1=160/70 \& Rev. Wage Ratio r2=160/125 }
\end{aligned}
$$

Therefore Total Impact as per $(3)=\{(1-0.14-0.08)(35)\}+\{(0.14) *(35) *(160 / 70)\}+\{(0.08) *(35) *(160 / 125)\}$

$$
=\$ 42.084 \text { ounce }
$$

While winding-up the Bretton Wood Regime the US dollar was devalued from \$35/per ounce to $\$ 42.22$ per ounce of gold, [9], US suspended the ability to freely convert between currency and gold, and the Gold Standard disappeared. Britain unpegged the Pound and, in effect, the brakes were removed, and the freely-traded currency was brought into effect. In his research paper, 'the Collapse of the Bretton Woods Fixed Exchange Rate System,' Peter M. Garber found 'the inflationary policy of the U.S. administration made a speculative attack inevitable. If the administration had been committed to less inflationary monetary policies, the basic Bretton Woods system would have remained intact.' Evidently proves that all the monetary tools US administration employed found blunt. Expansion of scope of minimum wage brought down the whole structure of Bretton Woods Fixed Exchange Rate System.

\section{Conclusion}

It is generally believed that inflation index helps to monitor inflation differentials \& therefore domestic inflation index is created by most of countries. It is true that domestic inflation index gives information about prices of domestic goods but does not provide information about cost of domestic goods. Therefore inflation index cannot help to monitor exchange rate and so also cannot control prices. One may not be wrong in claiming that all the existing monetary tools are found blunt. Whereas minimum wage, have in-built characteristic, which self-monitor inflation as well cost of domestic goods. Keeping in view the composition of food bundle prescribed under minimum wage and its rate sensitive nature there is need to employ as monetary tool rather than mere welfare measure.

Trading partners may not have to rely on monopolistic currency i.e. Dollar, Pound, and Euro etc. Dollar Index itself suggests that Dollar enjoys benefit of law of demand. It is as same as changing same currency either at premium or at discount. Trading partners, keeping in view the history, can decide independent exchange rate \& independent price of food at any point of time \& can move closer to ideal, one-world onecurrency.

Unilateral revision of minimum wage by either of the trading partners shall compel other party to review \& revise exchange rate and prices of goods. Trading partners shall require to be taken into confidence at time of up-rating. Simultaneous revision in minimum wage may help in stabilising \& maintaining exchange rates and so also food prices. Enabling platform, monitoring revision of minimum wage, should be provided by global financial institutions, i.e. World Bank, IMF,WTO etc\& ILO, to avoid volatility \& so also to achieve goal of food price control.

It is observed that quantities of production of food items, Fig.13, 14, 15 \& 16, always keep pace that with population. Governments around the world use trade policy to insulate their domestic food prices from 
global prices. Some insulate fully, some partly; all revert to political-economy target protection over time. This behaviour raises global volatility of food prices. Because insulation exports volatility elsewhere, when everyone does it, no one benefits. Countries that insulate most aggressively may export volatility to neighbours. Challenge to find ways to deal with this collective action problem, [10]. Therefore enforcing, periodic \& simultaneous, minimum wage revision, globally, on the basis of real growth rather than domestic inflation, is the only possible remedy to contain volatility in food price.

\section{References}

[1] Jonathan Wadsworth, Did the National Minimum Wage Affect UK Prices? Sept 2009, IZA DP No.4433 http://cep.lse.ac.uk/pubs/download/dp0947.pdf

[2] Department of Census and Statistics Sri Lanka, POVERTY STATISTICS/INDICATORS FOR SRI LANKA, http://www.statistics.gov.lk/poverty/PovertyStatistics.pdf

[3] Kaushik Basu, Chief Economic Adviser, MOI \& C. Marks, Professor ,Department of Economics, Cornell University Ithaca, New York5/2011) Understanding Inflation and Controlling It,

http://finmin.nic.in/workingpaper/understanding_inflation_controlling.pdf

[4] APEDA AGRI EXCHANGE, http://www.agriexchange.apeda.gov.in/

[5] Minimum Wage India, http://labourbureau.nic.in/Mini\%20Wages\%202k5\%20Intro.htm

[6] Survey prepared for AlaRM by R.P.I.R. Prasanna and B. Gowthaman. Sector specific Living Wage for Sr Lankan Apparel Industry Workers, https://www.modepoly.org/documents/06-ALaRM_LIVING_WAGE_sri_lanka.pdf

[7] Rabah Arezki,Prakash Loungani;IMF,Kaddour Hadri,Queen's University Management School, Yao Rao Liverpool Management School, Liverpool University, Breaking the Dynamic of Relative Primary Commodity Prices in Levels and Volatilities since1650, http://www.imf.org/external/np/seminars/eng/2012/commodity/pdf/hadri.pdf

[8] US minimum wage, http://www.dol.gov/whd/minwage/coverage.htm

[9] Peter M.Garber, the Collapse of the Bretton Woods Fixed Exchange Rate System,Chapter pages in book: (p. 461 - 494) http://www.nber.org/chapters/c6876

[10] Maros Ivanic \& Will Martin, Implications of price insulation for global food price volatility, 21 March 2013, http://www.imf.org/external/np/seminars/eng/2012/commodity/pdf/martin.pdf 